Piotr PANeK

\title{
DOŚWIADCZENIA ZWIĄZANE Z MIĘDZYNARODOWĄ EMIGRACJĄ ZAROBKOWA NA PRZYKŁADZIE STUDENTÓW UNIWERSYTETU EKONOMICZNEGO WE WROCŁAWIU
}

\begin{abstract}
WSTĘP
Rozwój techniki, globalizacja, a także procesy integracyjne powodują, że przemieszczanie się społeczeństwa pomiędzy dwoma miejscami stało się dostępne dla wielu, między innymi dla studentów, którzy w ostatnich latach starają się czerpać z takich przywilejów i jeśli tylko mają okazję, to decydują się na wyjazdy zagraniczne, gdzie jedną z możliwości jest podjęcie pracy zarobkowej. Nie wszyscy jednak mają taki sam cel podróży, dlatego autor artykułu starał się poznać motywy kierujące dzisiejszymi studentami.

Część z tych wojaży ma przede wszystkim wymiar czysto finansowy, a zdobyte podczas takiego wyjazdu środki finansowe mają służyć studentom przez cały rok akademicki. Dla innych praca podczas takiej eskapady jest tylko dodatkiem i ma za zadanie jedynie pokryć koszty utrzymania podczas takiej przygody, a sam wyjazd ma być formą aktywnego spędzenia wolnego czasu, podczas którego można poprawić znajomość języka obcego, nawiązać cenne znajomości, a także zdobyć doświadczenie, jakie niewątpliwie niesie za sobą wyjazd do innego kraju, gdzie można liczyć tylko na samego siebie.

Artykuł przedstawia istotę procesu migracji oraz przede wszystkim prezentuje dotychczasowe doświadczenia polskich studentów związane z międzynarodową emigracją zarobkową. Zostały w nim wykorzystane wyniki badania, które w 2010 roku zostało przeprowadzone wśród studentów Uniwersytetu Ekonomicznego we Wrocławiu.
\end{abstract}




\section{ISTOTA I KLASYFIKACJA POJĘCIA „MIGRACJA”}

W czasach, kiedy świat znajduje się w erze globalizacji, pojęcie migracji nabrało nowego znaczenia. Wzrost zainteresowania tematyką migracji spowodował wprowadzenie zmian w terminologii i rozwinięcie teoretycznych zagadnień związanych z tym zjawiskiem.

Studiując publikacje zajmujące się tym zjawiskiem, można natrafić na wiele definicji starających się wyjaśnić proces migracji.Jednym $z$ autorów jest Hieronim Kubiak, który postulował, aby za wyznacznik migracji uznać czas nie krótszy niż rok. Takie założenie również oddziela migrantów od pracowników sezonowych ${ }^{1}$.

Zjawisko migracji przedstawia także Andrzej Wierzbicki, który definiuje je jako przenoszenie się ludzi na znaczne dystanse i na długie okresy z różnych przyczyn i w różnych celach. Najczęstszą przyczyną jest chęć znalezienia pracy oraz lepszych niż we wcześniejszym środowisku zamieszkania warunków życia ${ }^{2}$. Natomiast Krystyna Slany przedstawiła migrację jako przestrzenne przemieszczenia ludności, które wynikają ze zmiany miejsca zamieszkania lub pobytu, z tą jednak różnicą, że są one świadome i zamierzone ${ }^{3}$.

Wprowadzając do definicji migracji dodatkowe czynniki, można ją bardziej uściślić i uszczegółowić. Jednym z takich elementów może być intencjonalność, ponieważ z reguły migranci są świadomi tego, że migrują. Wynika z tego, że migracji, którą jest względnie trwałe przemieszczanie się na nowe terytorium, towarzyszy uświadomione postanowienie, aby zamieszkać w nowym miejscu. Nie powoduje ono jednak wykluczenia przymusu, jakiemu podlegają na przykład uchodźcy czy wysiedleńcy, wskazuje jednak, że zmiana miejsca zamieszkania przez daną jednostkę dokonana jest w pełni świadomie, choć zdarza się, że niechętnie albo i wbrew woli. Na przymus ten mogą się składać najprzeróżniejsze czynniki - od finansowych po polityczne czy religijne. Tak więc dla socjologa nawet przymusowe migracje są wynikiem jednostkowych decyzji, które zostały podjęte indywidualnie po obliczeniu rachunku zysku i strat ${ }^{4}$. Wykorzystanie tutaj pojęcia intencjonalności powoduje, że nawet wyjazdy w celach turystycznych lub też wymian studenckich, które trwają relatywnie długi czas, nie muszą być migracją.

1 H. Kubiak, K. Slany, Migracje, [hasło w:] Encyklopedia socjologii, red. Z. Bokszański, Oficyna Naukowa, Warszawa 2002, s. 244.

2 A. Wierzbicki, Spoteczne aspekty migracji w kontekście integracji z Uniq Europejskq, [w:] Swobodny przeptyw pracowników w kontekście wejścia Polski do Unii Europejskiej, UKIE, Warszawa 2001, s. 183.

K. Slany, Między przymusem a wyborem: kontynentalne i zamorskie emigracje z krajów Europy Środkowo-Wschodniej, Wydawnictwo Uniwersytetu Jagiellońskiego, Kraków 1995, s. 22.

4 A. Kisiel, Postawy migracyjne studentów. Studium na przyktadzie Rybnika, [w:] Spoteczności lokalne: postawy migracyjne mtodych Polaków, red. A. Śliz, Wydawnictwo Uniwersytetu Opolskiego, Opole 2008, s. 124. 
Wraz z upływem czasu migracje nabierały nowego, specyficznego znaczenia, jakiego nigdy wcześniej nie miały. Mówiąc dokładniej, można by je zaliczyć do zbioru zachowań ludzkich. Międzynarodowa wędrówka straciła swój „walor” nadzwyczajności i wyjątkowości, ponieważ w dzisiejszych czasach może sobie na nią pozwolić prawie każdy mieszkaniec globu. Stała się ona zjawiskiem należącym do sfery otwartej ${ }^{5}$.

Współcześnie migracja staje się zjawiskiem globalnym, dotykającym coraz większą liczbę państw oraz procesem stale narastającym. Cechą charakterystyczną dzisiejszej migracji jest idąca w parze z globalizacją kompresja czasu i przestrzeni, co powoduje, że dla współczesnego społeczeństwa podróżowanie po świecie stało się łatwiejsze niż podróż po kraju kilkadziesiąt lat temu'.

Bardzo trafne wydaje się spostrzeżenie, że wiele organizmów państwowych przyłącza się do ponadnarodowych struktur, dlatego słuszniejsze jest stwierdzenie, że migracja to przemieszczanie się ludzi z jednej kultury do drugiej ${ }^{7}$.

Badane pojęcie można podzielić według kilku różnych kryteriów. Jednym $\mathrm{z}$ nich jest klasyfikacja ze względu na zasięg migracji (ze względu na ruch w przestrzeni fizycznej), która rozróżnia migracje zewnętrzne oraz migracje wewnętrzne (przemieszczenia wewnątrz danego kraju). Autor artykułu skupia się jedynie na migracji zewnętrznej.

Zajmując się kategorią migracji zewnętrznej, od razu należy rozróżnić trzy najważniejsze pojęcia związane $z$ omawianym zagadnieniem: emigracja, imigracja oraz reemigracja. Najprościej rzecz ujmując, emigracja jest to wyjazd z kraju pochodzenia do innego kraju, który najczęściej nazywany jest krajem przyjmującym, krajem pobytu lub też krajem goszczącym. Osoba, która opuszcza kraj pochodzenia, zwany też krajem rodzinnym, wypychającym, jest nazywana emigrantem. Natomiast imigracją jest napływ ludności z zagranicy do danego kraju i przebywanie w nim przez pewien okres. Wynika $\mathrm{z}$ tego, że imigrant jest to cudzoziemiec, obcokrajowiec w kraju goszczącym ${ }^{8}$. Imigracja jest bardzo często powiązana z otrzymaniem obywatelstwa kraju przyjmującego ${ }^{9}$. Jako reemigrację określamy sytuację polegającą na powrocie do państwa pochodzenia, z którego wcześniej się

\footnotetext{
P. Kaczmarczyk, M. Okólski, Migracje specjalistów wysokiej klasy w kontekście cztonkostwa Polski w Unii Europejskiej, UKIiE, Warszawa 2005, s. 7.

6 A. Śliz, Od podboju do dialogu kultur. Polskie migracje w kontekście procesu globalizacji. Zamiast wprowadzenia, [w:] Spoteczności lokalne: postawy migracyjne modych Polaków, red. A. Śliz, Wydawnictwo Uniwersytetu Opolskiego, Opole 2008, s. 10.

7 H. Mamzer, Tożsamośc w podróży. Wielokulturowośc a ksztattowanie tożsamości jednostki, Wydawnictwo Naukowe Uniwersytetu im. Adama Mickiewicza, Poznań 2003, s. 133-134.

8 Ibidem, s. 15.

9 N. Romaniuk, Dialektyka wyzwań i zagrożeń bezpieczeństwa: aspekt migracyjny, [w:] Migracja- wartość dodana, red. K. Markowski, Wydawnictwo Katolickiego Uniwersytetu Lubelskiego, Lublin 2008, s. 134.
} 
emigrowało, po dłuższym okresie nieobecności. Powrót ten jest zorganizowany na własną rękę (w odróżnieniu od repatriacji $)^{10}$.

Podsumowując, można zauważyć, że osoba, która przemieszcza się pomiędzy dwoma krajami, jest zarówno emigrantem (według kraju pochodzenia), jak i imigrantem (według kraju przyjmującego). Wynika to $\mathrm{z}$ faktu, że emigrując z jednego kraju, imigruje się do drugiego.

Pojęcie migracji można również sklasyfikować ze względu na przyczynę decyzji migracyjnych. Przyjmując to jako kryterium, możemy ją podzielić na dobrowolną oraz na przymusową. Innym podziałem jest klasyfikacja ze względu na główny cel migracji. Poddając dywersyfikacji kolejne kryterium, możemy rozróżnić migracje z powodów ekonomicznych oraz migracje pozaekonomiczne (główne cele nie są nastawione na osiąganie korzyści ekonomicznych, jednak jedno nie wyklucza drugiego). Zarówno pierwsze, jak i drugie mogą dotyczyć migrantów wewnętrznych oraz zewnętrznych.

Wcześniej wspomniano o tym, że czynnikiem, który może poróżnić badaczy, jest okres, na jaki migruje dana osoba. Stąd też powstała klasyfikacja ze względu na czas trwania migracji. Różne źródła odmiennie postrzegają zjawisko migracji. Dla jednych migracją jest nie tylko kilkuletni wyjazd za granicę, ale również wyjazd na kilka dni, a także codzienne przekraczanie granicy w celach zarobkowych. Jednak inni te same sytuacje traktują całkiem odmiennie. Jako kryterium przyjęli oni okres 3 miesięcy. Wszystkie wyjazdy trwające krócej niż przyjęte 3 miesiące nie są przez nich traktowane jako migracje. Tak więc za migrantów nie uznają oni dyplomatów, turystów, pielgrzymów, żołnierzy na misjach wojskowych itp. ${ }^{11}$ Autor tej pracy za migrację uznaje każde przekroczenie granicy państwowej.

Różnicując migrację według kryterium czasu jej trwania, głównym podziałem jest wyróżnienie na migrację stałą (trwałą, osiedleńczą) oraz na migrację tymczasową. Migracja stała charakteryzuje się tym, że dana osoba ma plany i chęci spędzenia całego życia poza granicami kraju ojczystego. Termin migracje tymczasowe jest dużo bardziej rozbudowany. Ma ona dwie cechy: każde przekroczenie granicy kraju pochodzenia trwa pewien okres oraz migranci planują powrót do kraju, z którego wyjechali ${ }^{12}$.

W tym momencie również pojawiają się rozbieżności co do podziału migracji tymczasowych. Zdaniem autora najbardziej trafny jest podział na migracje epizodyczne (wyjazd służbowy, rekreacyjny oraz inne wyjazdy nieregularne), majątkowe (codzienne, bądź cotygodniowe wyjazdy do miejsc pracy znajdujących się poza

10 „Biuletyn migracyjny”, Ośrodek Badań nad Migracjami Uniwersytetu Warszawskiego, nr 2/ /sierpień 2005, Warszawa 2005, s. 8.

11 Z. Kawczyńska-Butrym, Migracje. Wybrane zagadnienia, Lublin 2009, s. 21.

12 N. Romaniuk, op. cit., s. 133. 
granicami danego państwa, np. „mrówki”) i sezonowe (wyjazd w celach zarobkowych na okres kilku tygodni lub miesięcy, po upływie którego następuje powrót do kraju pochodzenia, np. praca w rolnictwie lub budownictwie $)^{13}$.

Ostatnim opisanym przez autora podziałem migracji jest klasyfikacja ze względu na legalność migracji. Status prawny migranta dzieli migrację na legalną i nielegalną oraz na okres przejściowy, który dotyczy osób ubiegających się o pozostanie w danym kraju zgodnie z literą prawa (osób starających się o azyl, pozwolenie na pracę, edukację, ,pobyt tolerowany" $\left.{ }^{14}\right)$.

\section{OPIS METODY BADAWCZEJ}

Do napisania artykułu zostały wykorzystane wyniki badania ankietowego (ilościowego), jakie zostało przeprowadzone wśród studentów Wydziałów: Nauk Ekonomicznych; Zarządzania, Informatyki i Finansów oraz Inżynieryjno-ekonomicznego Uniwersytetu Ekonomicznego we Wrocławiu. W badaniu wzięło udział 707 studentów (10\% wszystkich studentów studiujących na trzech wydziałach Uniwersytetu Ekonomicznego we Wrocławiu). Ankieta składała się z 38 pytań, z których wszystkie miały formę zamkniętą, a część z nich była dodatkowo tak skonstruowana, że w przypadku braku pasującej respondentowi odpowiedzi dawała możliwość wpisania własnej. Próba badawcza została dobrana ze względu na wydział, rok studiów, kierunek, specjalizacje oraz płeć studentów. Badania były przeprowadzane podczas wykładów w semestrze letnim roku akademickiego 2009/2010.

Głównymi powodami zrealizowania badania była chęć ustalenia:

1) jaka była wielkość emigracji zarobkowej studentów Uniwersytetu Ekonomicznego we Wrocławiu?

2) jakie były kierunki emigracji zarobkowej studentów Uniwersytetu Ekonomicznego we Wrocławiu?

3) jakie były korzyści i wady emigracji zarobkowej w czasie trwania edukacji na Uniwersytecie Ekonomicznym we Wrocławiu?

13 Ibidem.

14 Zgoda na pobyt tolerowany jest jedną z czterech form ochrony, jakie imigrant może otrzymać w Polsce (pozostałe trzy to: status uchodźcy, ochrony czasowej, azylu). Zgoda na pobyt tolerowany jest przyznawana w sytuacji, kiedy ewentualny powrót zainteresowanej osoby do kraju mógłby stanowić zagrożenie dla jego życia lub zdrowia (Zob. „Biuletyn migracyjny”, Wydawnictwo Ośrodka Badań nad Migracjami Uniwersytetu Warszawskiego, nr 1/czerwiec 2005, s. 8). 


\section{ANALIZA WYNIKÓW BADANIA ANKIETOWEGO DOTYCZAZCEGO DOTYCHCZASOWEJ MIĘDZYNARODOWEJ EMIGRACJI ZAROBKOWEJ STUDENTÓW UNIWERSYTETU EKONOMICZNEGO WE WROCŁAWIU}

Jak przedstawiono we wcześniejszej części artykułu, wyjazdy za granicę są coraz bardziej popularne, a ich ogólna dostępność sprawia, że stają się one jeszcze powszechniejsze. Dlatego nie może dziwić fakt, że 95,7\% studentów Uniwersytetu Ekonomicznego we Wrocławiu przynajmniej raz było poza granicami Polski. Jednak dla większości respondentów powodem czasowego opuszczenia kraju był przede wszystkim cel turystyczny $(85,7 \%)$, a dopiero w drugiej kolejności zarobkowy $(28,5 \%)$. Inną przyczyną wyjazdów zagranicznych może być cel edukacyjny, czyli różnego rodzaju wymiany studentów i programy typu LLP Erasmus, na które zdecydowało się 11,5\% studentów UE we Wrocławiu.

Wyjazdy zarobkowe były bardziej popularne wśród mężczyzn niż kobiet (odpowiednio 31,3\% i 26,5\%), natomiast cel turystyczny oraz edukacyjny był częściej wskazywany przez kobiety.

Nie może zaskakiwać fakt, że wśród studentów $\mathrm{V}$ roku ponad połowa $(55,2 \%)$ była za granicą w celach zarobkowych. Odsetek ten zmniejszał się wraz z rokiem studiów i wśród studentów I roku wyniósł 18,1\%.

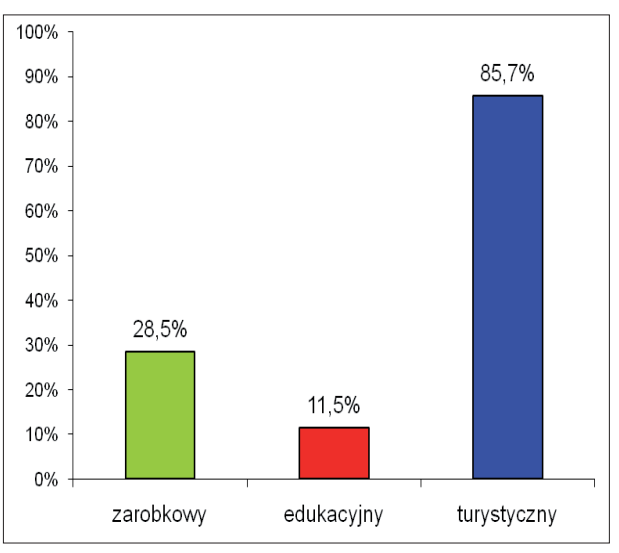

Wykres 1. W jakim celu wyjechałeś/aś za granicę? $\mathrm{N}=677$

* Odsetki nie sumują się do 100\%, ponieważ respondenci mogli wskazać więcej niż jedną odpowiedź.

Źródło: opracowanie własne na podstawie zrealizowanego badania ankietowego.

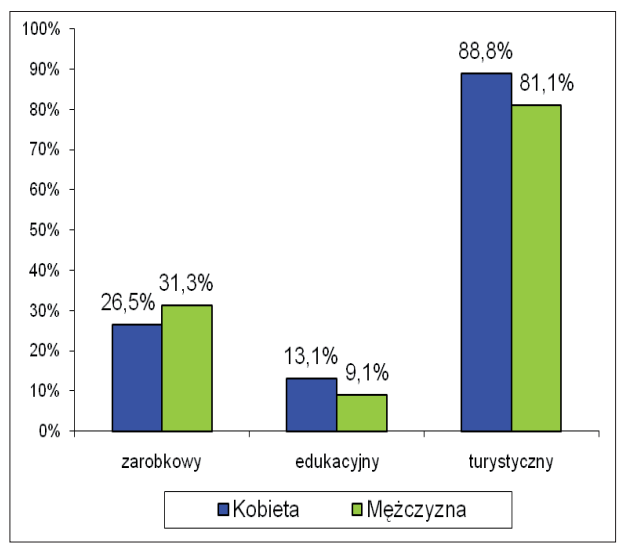

Wykres 2. W jakim celu wyjechałeś/aś za granicę? (z podziałem na płeć) $\mathrm{N}=677$

* Odsetki nie sumują się do $100 \%$, ponieważ respondenci mogli wskazać więcej niż jedną odpowiedź.

Źródło: jak w wykresie 1. 
W dalszej części artykułu autor skupi się jedynie na prezentacji odpowiedzi, jakich udzielili studenci, którzy przynajmniej jeden raz byli za granicą w celach zarobkowych. Spośród respondentów, którzy mają doświadczenie $\mathrm{w}$ pracy za granicą, ponad połowa $\mathrm{z}$ nich (55\%) przyznała, że jak na razie był to ich jedyny raz. Jednak zapewne wiele $z$ tych osób nie zakończy swoich doświadczeń na tym pojedynczym przypadku. Również liczba tego rodzaju wyjazdów układała się w pewien malejący ciąg, ponieważ dwa wyjazdy do pracy wskazało $26,3 \%$ studentów, trzykrotnie w pracy za granicą było $12,3 \%$ respondentów, natomiast cztery i więcej razy za granicą w celach zarobkowych było $6,4 \%$ osób.

Brak odpowiednich kwalifikacji przyszłych absolwentów powodował, że zdecydowana większość studentów podejmowała prace o charakterze fizycznym. Jedynie małej części osób udało się pracować umysłowo, w takich pracach jak pilot wycieczek, animator lub pomoc biurowa. Część osób znajdowała zatrudnienie $\mathrm{w}$ ambasadach i domach brokerskich $\mathrm{w}$ ramach odbywanych przez nich staży i praktyk. Najbardziej popularnymi pracami dla wspomnianej wcześniej większości były posady kelnera i barmana (w sumie 25,2\%), praca w ogrodnictwie $(18,7 \%)$, a także jako opiekun do dzieci i starszych osób, na budowie, $\mathrm{w}$ gastronomii, $\mathrm{w}$ magazynie, $\mathrm{w}$ fabryce, przy taśmie produkcyjnej i przy sprzątaniu (od 4,7 do 12,3\%). Niektórzy studenci znajdowali zatrudnienie w bardziej egzotycznych branżach, takich jak praca przy renowacji zamku, jako modelka, jako elektryk, jako kierowca rikszy lub pracownik ochrony.

Różnorodność branż sugeruje, że dla studentów najważniejszym czynnikiem determinującym decyzje o wyjeździe były przede wszystkim wysokość zarobków oraz obcowanie $\mathrm{z}$ językiem, co zostało przedstawione w dalszej części pracy.

Najatrakcyjniejszymi krajami (wykres 3), do których studenci wyjeżdżali w poszukiwaniu pieniędzy, doświadczenia i przygody, były Anglia (38,6\%), Niemcy $(32,7 \%)$ oraz Holandia (15,8\%). Można to wytłumaczyć preferencjami studentów przy wyborze kraju, ponieważ Anglia motywowała nie tylko wysokimi zarobkami, ale również możliwością doskonalenia umiejętności językowych najpopularniejszego języka świata. Nasi zachodni sąsiedzi swoją wysoką pozycję zawdzięczali popularności sprzed kilku lat, kiedy to wiele osób pracowało tam przede wszystkim w ogrodnictwie, przy zbiorze owoców. Holandia, podobnie jak Niemcy, zachęcała wysokimi zarobkami i niskimi kosztami utrzymania w czasie prac sezonowych (wieloosobowe pokoje oferowane przez pracodawcę). 


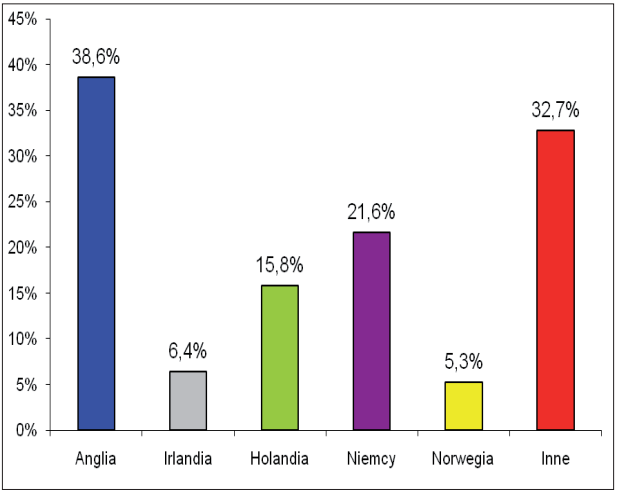

Wykres 3. W jakim kraju podjąłeś/jęłaś pracę? $\mathrm{N}=202$

* Odsetki nie sumują się do 100\%, ponieważ respondenci mogli wskazać więcej niż jedną odpowiedź.

Źródło: jak w wykresie 1.

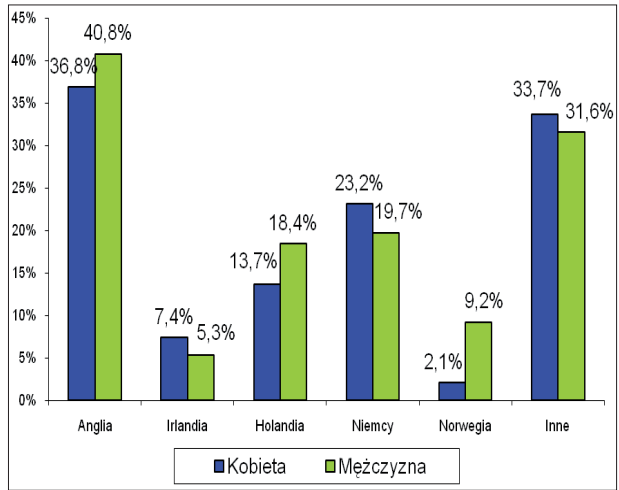

Wykres 4. W jakim kraju podjąłeś/jęłaś pracę? (z podziałem na płeć) $\mathrm{N}=202$

* Odsetki nie sumują się do $100 \%$, ponieważ respondenci mogli wskazać więcej niż jedną odpowiedź.

Źródło: jak w wykresie 1.

Wśród krajów wymienionych przez studentów wysoką pozycję zajęły również Stany Zjednoczone (11,7\%). W większości przypadków osoby wyjeżdżały do tego kraju, korzystając z programów studenckich typu Work \& Travel, które często oferowały ciekawe miejsca zatrudnienia, a po wygaśnięciu kontraktu umożliwiały zwiedzanie kraju (we własnym zakresie).

Sporą część państw stanowiły kraje turystyczne, takie jak Hiszpania, Włochy, Cypr i Grecja, które oferowały pracę w hotelach, pubach i restauracjach. Bardzo popularnymi krajami, do których czasowo emigrowali studenci, były kraje skandynawskie (w sumie 8,8\% ankietowanych), które zachęcały przede wszystkim bardzo atrakcyjnymi zarobkami. Wśród badanej grupy znalazło się również kilka osób, które za cel swojego wyjazdu obrały mniej popularne kraje, między innymi takie jak Australia, Indie, Kanada, Luksemburg i Ukraina.

Najbardziej popularnym terminem wyjazdów do pracy był okres wakacji letnich (94,7\%). Przy umiejętnym rozłożeniu terminów egzaminów na studiach długość przerwy pomiędzy semestrem letnim i zimowym mogła wynosić nawet ponad trzy miesiące, co dawało wiele możliwości wyjazdu za granicę. Poza tym $\mathrm{w}$ wielu pracach sezonowych właśnie w tych miesiącach było i jest największe zapotrzebowanie na pracowników.

Z kolei mała liczba osób decydujących się na wyjazd w przerwie zimowej (2,3\%) mogła być spowodowana relatywnie małą liczbą dni wolnych. W rezultacie powodowało to, że podróże za granicę stawały się nieopłacalne, ponieważ sam wyjazd również wiązał się z pewnymi kosztami, które mogłyby się nie zwrócić w tak krótkim czasie. Natomiast na wyjazd w okresie nauki zdecydowało się 11,7\% studentów. 
Uwzględniając podział ze względu na rok studiów, można zauważyć zdecydowany wzrost odsetku studentów piątego roku wyjeżdżających z Polski do pracy w okresie nauki (25\%) w porównaniu ze studentami młodszych lat (od 7,7 do 10\%). Na zaistniałą sytuację mogło mieć wpływ uświadomienie sobie przez najstarszych studentów, że jest to ostatni moment na dłuższy zagraniczny wyjazd, podczas którego mogliby podnieść swoją znajomość języka obcego, zdobyć cenne doświadczenie, a także zgromadzić oszczędności, które mogłyby w przyszłości pozwolić im na rozpoczęcie własnej działalności, kupno mieszkania lub samochodu. Ta sytuacja w konsekwencji prowadziła do skorzystania przez nich z urlopu dziekańskiego. $Z$ takiego przywileju skorzystało aż 18,8\% studentów $V$ roku. $\mathrm{Z}$ kolei odsetek studentów, którzy podjęli decyzję o przerwaniu na rok nauki, wyniósł w sumie dla czterech pozostałych roczników 13,7\%.

Jak już wcześniej zostało wspomniane, najbardziej atrakcyjne wśród studentów były wyjazdy w czasie letnich wakacji, dlatego nie może dziwić fakt, że najczęściej trwały one od miesiąca do trzech miesięcy $(80,1 \%)$. W dalszej kolejności ankietowani wskazali wyjazdy nie dłuższe niż 30 dni (12,9\%), 4-6 miesięcy (9,4\%), 6-12 miesięcy (4,7\%). Najmniej popularne były wyjazdy przekraczające rok, na które zdecydowało się w przeszłości 4,1\% respondentów.

Wysokość miesięcznego wynagrodzenia otrzymywanego przez studentów za pracę na obczyźnie (wykres 5) osiągnęła swoją dominantę w przedziale od 2501 zł do 4500 zł $(49,1 \%)$. Taki poziom wynagrodzenia był bardzo atrakcyjny zarówno dla zagranicznego pracodawcy, który dzięki temu mógł obniżyć koszty swojej działalności, a także dla polskiego pracownika, który w porównaniu z zarobkami osiąganymi w ojczyźnie był w stanie oszczędzić większą kwotę pieniędzy.

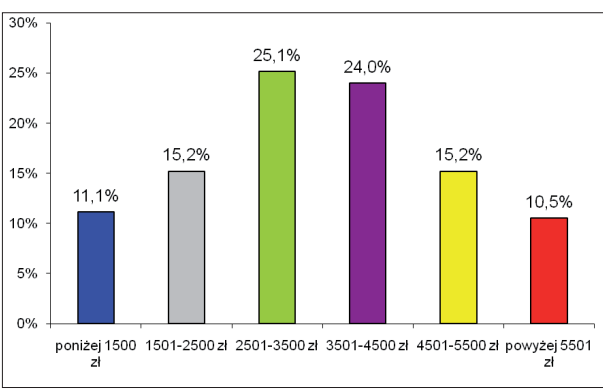

Wykres 5. Jakie wynagrodzenie miesięcznie otrzymywałeś/aś z tytułu pracy za granicą w przeliczeniu na PLN, brutto? $\mathrm{N}=202$

* Odsetki nie sumują się do 100\%, ponieważ respondenci mogli wskazać więcej niż jedną odpowiedź.

Źródło: jak w wykresie 1.

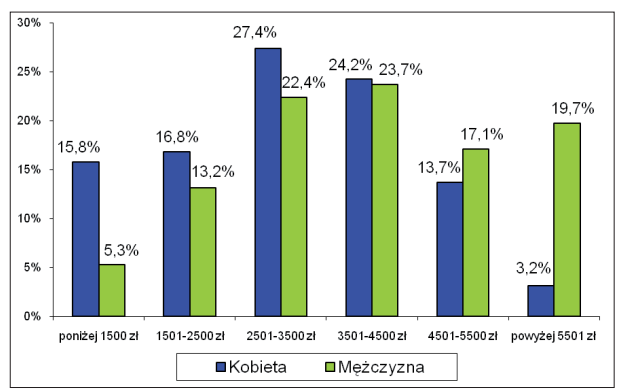

Wykres 6. Jakie wynagrodzenie miesięcznie otrzymywałeś/aś z tytułu pracy za granicą w przeliczeniu na PLN, brutto? (z podziałem na płeć) $\mathrm{N}=202$

* Odsetki nie sumują się do 100\%, ponieważ respondenci mogli wskazać więcej niż jedną odpowiedź. Źródło: jak w wykresie 1. 
Bardzo ciekawie przedstawiają się wyniki dotyczące wysokości otrzymywanego wynagrodzenia $\mathrm{z}$ podziałem ze względu na płeć. Na wykresie 6 widać, że mężczyźni stanowili zdecydowaną większość w grupie osób, których wynagrodzenia przekraczały poziom 4501 zł. Odsetek mężczyzn rósł wraz ze wzrostem poziomu zarobków, natomiast odsetek kobiet $\mathrm{w}$ tych przedziałach diametralnie spadał. Wpływ na taką sytuację mógł mieć rodziaj pracy podejmowanej za granicą. Dobrze płatna praca na budowie i przy remontach była wykonywana głównie przez mężczyzn. Na przeciwległym biegunie znalazły się między innymi prace w hotelach (kelner, pokojówka) i restauracjach (kelner, barman), które były gorzej opłacane między innymi z tego względu, że pracodawca bardzo często dodatkowo oferował, oprócz wynagrodzenia, zakwaterowanie i wyżywienie, co wpływało na niższy poziom zarobków.

Najpopularniejszą formą poszukiwania ofert pracy za granicą (wykres 7) nie były agencje (biura) pośrednictwa pracy ani Internet. Duży odsetek osób decydował się na wyjazd po poszukiwaniach na własną rękę (38,0\%), jednak zdecydowana większość osób korzystała z doświadczeń i kontaktów znajomych $(56,1 \%)$, którzy w przeszłości przynajmniej raz byli za granicą w celach zarobkowych. Wpływ na wysoki odsetek formy poszukiwania pracy wśród znajomych miał fakt styczności na studiach z rówieśnikami, którzy wzajemnie sobie polecali miejsca wyjazdów i pomagali przy organizacji takiego rodzaju spędzania czasu.

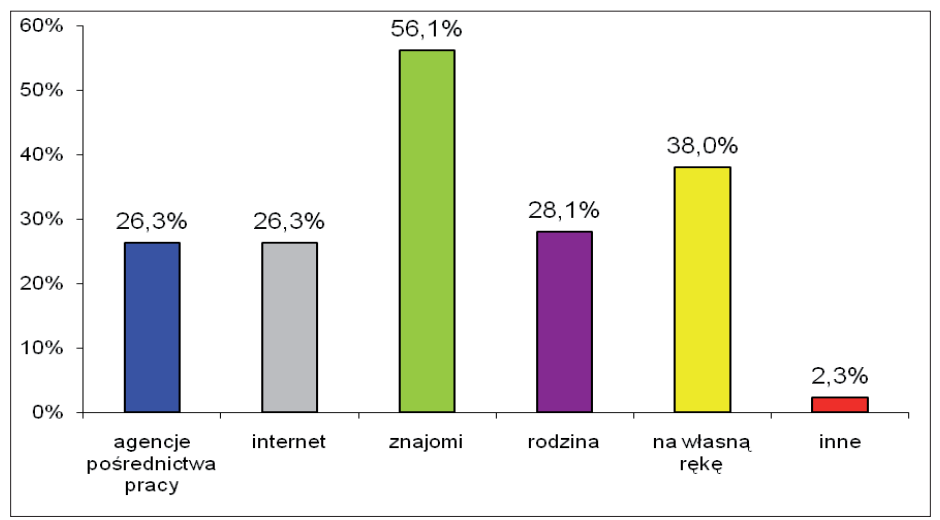

Wykres 7. Gdzie szukałeś/aś ofert pracy za granicą? N= 202

* Odsetki nie sumują się do 100\%, ponieważ respondenci mogli wskazać więcej niż jedną odpowiedź.

Źródło: jak w wykresie 1.

Powodem niskiej popularności agencji pośrednictwa pracy za granicą może być fakt braku ufności do tego rodzaju biur, ponieważ nie zawsze budzą one zaufanie klientów. Poza tym zawarcie umowy z takim pośrednikiem zawsze wią- 
że się z pobieraną przez niego prowizją za pomoc $\mathrm{w}$ poszukiwaniu pracy, często niewspółmierną do gwarantowanego zakresu pomocy. Podobne wsparcie, jakie oferują biura pośrednictwa pracy, jednak bez ponoszenia kosztów, można uzyskać od znajomych, którzy wcześniej pracowali zarobkowo za granicą. Takie relacje często opierają się na wzajemnym zaufaniu, wypracowywanym od początku znajomości. Gwarantuje to pomoc w szerszym zakresie, niż są to w stanie zapewnić wspomniane wcześniej agencje.

Innymi sposobami na znalezienie pracy za granicą, wskazywanymi przez ankietowanych, były również oferty organizacji studenckich, a także takich podmiotów jak Związek Harcerstwa Rzeczypospolitej.

Opisaną wyżej prawidłowość potwierdzają kolejne wyniki badania. $\mathrm{Na}$ wykresie 8 zdecydowanie przeważają wspólne wyjazdy ze znajomymi (60,2\%). Składały się na nie zarówno wspólne wyjazdy realizowane na własną rękę, jak i te organizowane przez agencje pośrednictwa pracy, ponieważ decyzje o wyjeździe są łatwiejsze do podjęcia w przypadku, gdy ma się towarzystwo innej osoby.

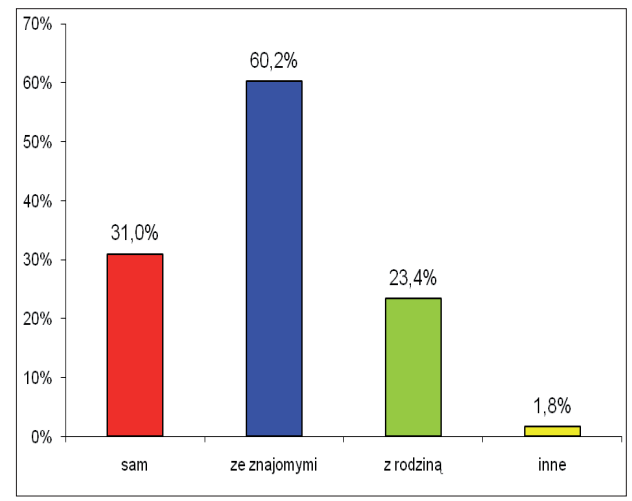

Wykres 8. Z kim wyjeżdżałeś/aś do pracy za granicę? $\mathrm{N}=202$

* Odsetki nie sumują się do $100 \%$, ponieważ respondenci mogli wskazać więcej niż jedną odpowiedź.

Źródło: jak w wykresie 1.

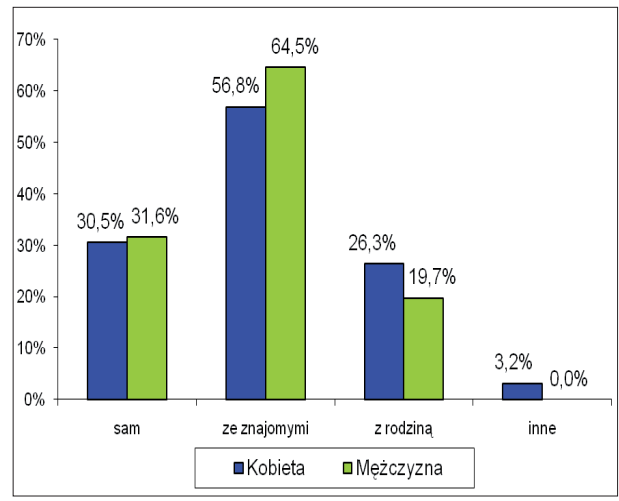

Wykres 9. Z kim wyjeżdżałeś/aś do pracy za granicę? (z podziałem na płeć) $\mathrm{N}=202$

* Odsetki nie sumują się do $100 \%$, ponieważ respondenci mogli wskazać więcej niż jedną odpowiedź.

Źródło: jak w wykresie 1.

Małym zakoczeniem może być przedstawiony na wykresie 9 prawie równy odsetek kobiet i mężczyzn, którzy zdecydowali się na samotny wyjazd (w obu przypadkach nieco ponad 30\%). Z kolei wspólne wyjazdy z członkiem rodziny były preferowane przez kobiety (26,3\%). Mężczyźni najczęściej decydowali się na wyjazdy ze znajomymi (64,5\%). 
Jedynie niewiele ponad 25\% studentów decydowało się ponownie wrócić do miejsc pracy, gdzie wcześniej ją wykonywali. Mogło być kilka powodów takiego zachowania. $Z$ jednej strony wpływ na to mogło mieć niezadowolenie $z$ warunków danej pracy i chęć znalezienia innego, lepszego zajęcia (lepiej płatnego, lżejszego). Być może osoby pracujące $\mathrm{w}$ danym miejscu poszukiwały zatrudnienia w innym miejscu, do którego przyjeżdżały kolejnym razem. Również zdobyte doświadczenie wpływało na możliwość zmiany rodzaju wykonywanej przez nich pracy na bardziej korzystną.

Część osób, która nigdy nie pracowała ponownie w tym samym miejscu, przy okazji kolejnej podróży za granicę po prostu zmieniała kraj wyjazdu zarobkowego. Motywem ich działań mogła być chęć poznania nowych języków, zwiedzenia nowych miejsc, zawarcia nowych znajomości. Takie działania są pozytywnie odbierane przez późniejszych pracodawców, dla których liczy się odwaga, kreatywność i zdobyte doświadczenie. Jest to duża zaleta osób poszukujących pracy po zakończeniu swojej edukacji.

$\mathrm{Z}$ uwagi na to, że badanie obejmowało studentów studiów ekonomicznych, można było zakładać, że spora część zarobionych przez nich pieniędzy powinna być w jakiś sposób zainwestowana. Jednak wykres 10 przedstawia, jak bardzo mylne było wstępne założenie. Najwięcej pieniędzy zostało przeznaczonych na konsumpcję (71,3\%), w drugiej kolejności na edukację (42,7\%), a dopiero trzecią z najpopularniejszych form przeznaczenia zarobionych pieniędzy było odłożenie ich na późniejsze wydatki.

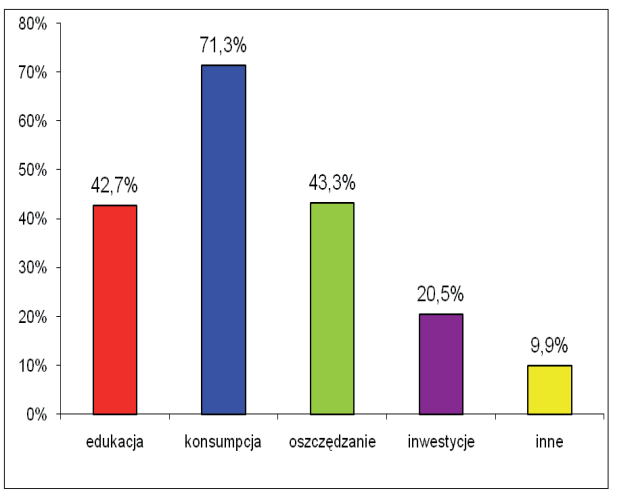

Wykres 10. Na co przeznaczałeś/aś zarobione za granicą pieniądze? $\mathrm{N}=202$

* Odsetki nie sumują się do 100\%, ponieważ respondenci mogli wskazać więcej niż jedną odpowiedź.

Źródło: jak w wykresie 1.

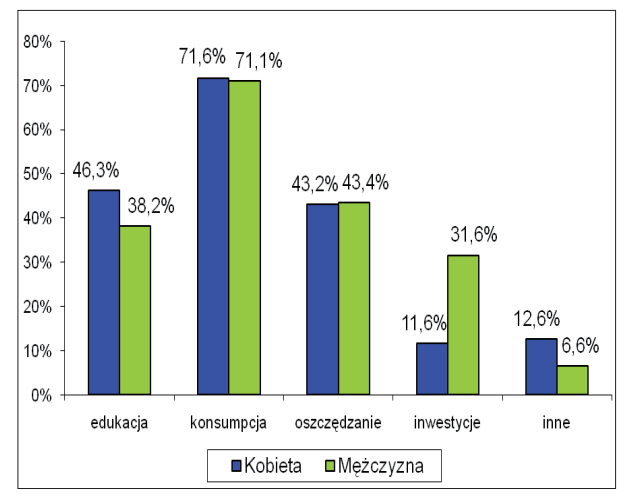

Wykres 11. Na co przeznaczałeś/aś zarobione za granicą pieniądze? (z podziałem na płeć) $\mathrm{N}=202$

* Odsetki nie sumują się do 100\%, ponieważ respondenci mogli wskazać więcej niż jedną odpowiedź.

Źródło: jak w wykresie 1. 
Porównując pod tym względem preferencje kobiet i mężczyn (wykres 11), istotną różnicą widzimy jedynie w trzech przypadkach. Wyraźnie wyższy odsetek mężczyzn decydował się na zainwestowanie zgromadzonych pieniędzy, natomiast kobiety górowały nad mężczyznami, inwestując w swoją edukację oraz wskazały inne formy spożytkowania zarobionych pieniędzy. Najczęściej wymieniane przez respondentów inne przykłady przeznaczenia zgromadzonych środków to wydatki związane z podróżami, zakup laptopów, samochodów, a także finansowa pomoc rodzinie.

Zagraniczne wojaże, nawet te krótkookresowe, zawsze były idealną okazją do doskonalenia poznanego wcześniej języka, a także do nauki nowego języka od podstaw. Jednakże nie zawsze taka możliwość była wykorzystywana przez osoby pracujące za granicą. Wśród badanych osób zdecydowana większość starała się jednak cennie wykorzystać szansę na podnoszenie swoich umiejętności językowych (83\%), co w przyszłości, po zakończeniu edukacji wyższej, może stać się ich dodatkowym atutem podczas poszukiwań pracy w Polsce, a przede wszystkim poza jej granicami. Zważywszy że badanie dotyczyło studentów, może zastanawiać, że aż $17 \%$ ankietowanych osób nie doskonaliło podczas wyjazdu żadnego języka obcego. Wytłumaczeniem tej sytuacji może być fakt, że rodzaj wykonywanej pracy być może nie pozwalał im na szerszy kontakt z obcym językiem (praca wśród rodaków), a wymagania stawiane przez przełożonych powodowały, że nie mieli oni ani sił, ani czasu na naukę języka we własnym zakresie.

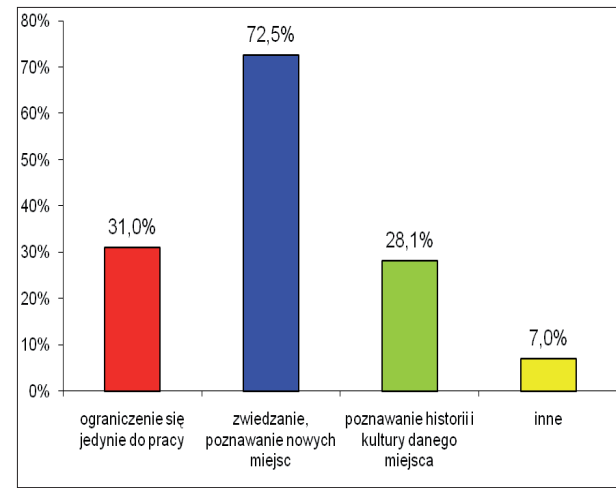

Wykres 12. Co oprócz pracy robiłeś/aś podczas wyjazdu zarobkowego za granicą? $\mathrm{N}=202$

* Odsetki nie sumują się do 100\%, ponieważ respondenci mogli wskazać więcej niż jedną odpowiedź.

Źródło: jak w wykresie 1.

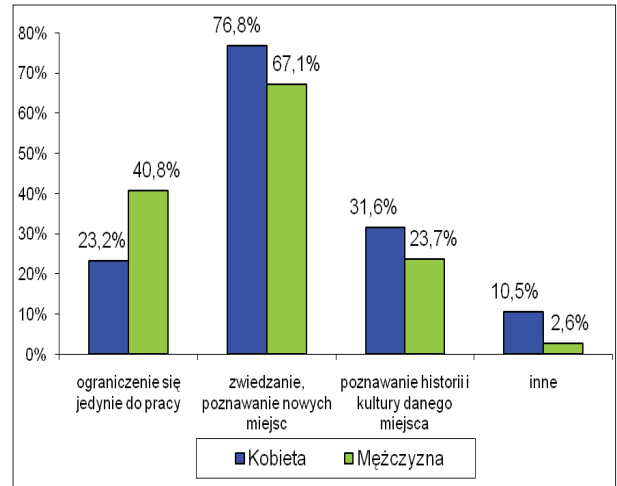

Wykres 13. Co oprócz pracy robiłeś/aś podczas wyjazdu zarobkowego za granicą? (z podziałem na płeć) $\mathrm{N}=202$

* Odsetki nie sumują się do $100 \%$, ponieważ respondenci mogli wskazać więcej niż jedną odpowiedź.

Źródło: jak w wykresie 1. 
Podsumowując omawianą kwestię, można stwierdzić, że pozytywnym zjawiskiem jest chęć nauki języka obcego przez tak duży odsetek studentów Uniwersytetu Ekonomicznego. Należy mieć nadzieję, że mniejszość niewykorzystująca tej szansy, jaką daje zagraniczny wyjazd, nie robiła tego z własnej woli, lecz po prostu wykonywane przez nią obowiązki nie pozwalały jej w pełni czerpać z możliwości własnego rozwoju.

Język angielski, z racji swojej popularności, był językiem najczęściej używanym przez studentów Uniwersytetu Ekonomicznego we Wrocławiu podczas ich pracy za granicą. W tym czasie doskonaliło go aż 71,4\% osób. Kolejnymi wskazanymi językami były niemiecki (18,7\%), hiszpański (6,4\%), włoski i holenderski (1,8\%). Pojedyncze osoby po powrocie do kraju mogły się pochwalić znajomością takich języków obcych, jak francuski, rosyjski, słowacki oraz norweski, duński i islandzki.

Przy okazji pobytu za granicą bardzo powszechną rzeczą było poszerzanie własnej wiedzy na temat okolicy, w której się przebywało (wykres 12). Aby wyjazd kojarzył się nie tylko z ciężką pracą, ale również z przyjemniejszymi wspomnieniami, bardzo popularne wśród młodzieży było zwiedzanie danego miejsca, jego zabytków oraz atrakcji, jakie oferowało, co potwierdziło 72,5\% badanych osób. Dużo mniej rozpowszechnionym zachowaniem było poznawanie historii i kultury danego miejsca czy regionu $(28,1 \%)$.

Wspomniane procesy w większym stopniu dotyczą kobiet, które w obu przypadkach miały przewagę nad mężczyznami (wykres 13). Z kolei odsetek mężczyzn, którzy ograniczali się jedynie do wykonywanej w danym czasie pracy, był prawie dwukrotnie wyższy niż kobiet. Na taki stan mógł mieć wpływ rodzaj wykonywanej pracy (ciężka praca fizyczna, nadgodziny w pracy), a także podejmowanie zatrudnienia w więcej niż jednym miejscu, co wpływało na mniejszą ilość wolnego czasu.

Bardzo częstą praktyką było planowanie wyjazdu w taki sposób, żeby na początku emigracji skupić się na pracy zarobkowej, a dopiero po jej zakończeniu poświęcić czas na zwiedzanie okolicy albo wybranego wcześniej regionu danego kraju. Takie standardy były realizowane między innymi w ramach wspomnianego w pracy programu Work \& Travel USA, podczas którego osoby biorące w nim udział otrzymywały wizę, która upoważniała ich do trzymiesięcznej pracy zarobkowej oraz dodatkowo dawała im możliwość zwiedzania kraju przez kolejny miesiąc.

Osoby biorące udział w badaniu udzielały również innych odpowiedzi, gdzie najczęściej podawanymi formami spędzania czasu wolnego od pracy było zawieranie nowych znajomości oraz udział w zabawach i dyskotekach.

Studenci decydujący się na wyjazd za granicę w celu zarobkowym liczą, że po powrocie będą mogli stwierdzić, że owa ekspedycja była warta wyrzeczeń. Spośród studentów Uniwersytetu Ekonomicznego we Wrocławiu jedynie co dziesiąta osoba nie była zadowolona z zagranicznej wyprawy. Większy odsetek osób 
usatysfakcjonowanych $\mathrm{z}$ wyprawy stanowiły kobiety (różnica ponad 8 punktów procentowych w porównaniu z mężczyznami).

Ocena studentów po ich powrotach do kraju pokrywała się mniej więcej z opinią, jaką przekazaliby na temat zagranicznych wyjazdów zarobkowych innym osobom. Ponad $87 \%$ osób poleciłoby taki wyjazd innym, co może sugerować, że nie tylko byli oni zadowoleni z pracy $\mathrm{w}$ danym miejscu, zastanych tam warunków życiowych, ale również nie traktowaliby oni tych osób jako potencjalnej konkurencji na rynku pracy.

Najczęściej polecanymi przez studentów kierunkami emigracji zarobkowej były kraje Zjednoczonego Królestwa (blisko 34\%), kraje skandynawskie (27\%), Niemcy (17\%), kraje Beneluksu (16\%), Stany Zjednoczone (12\%) oraz Hiszpania i Irlandia (po 7\%). Blisko 5\% ankietowanych zarekomendowało zagraniczny wyjazd bez wskazania nazwy konkretnego kraju. Mały odsetek osób poleciłby wyjazd do takich krajów, jak Australia, Grecja, Włochy, Francja, Austria, Szwajcaria oraz Cypr. Jak widać, zdecydowaną większość stanowiły kraje europejskie, należące do Unii Europejskiej i anglojęzyczne.

\section{ZAKOŃCZENIE}

Podsumowując zebrane podczas badania informacje, można stwierdzić, że zjawisko międzynarodowej emigracji zarobkowej wśród studentów jest bardzo popularne, a wzrost jej dostępności spowoduje, że w przyszłości jej skala będzie się stale powiększać. Dzisiejsza młodzież wie, że taka forma spędzania czasu jest swego rodzaju inwestowaniem $\mathrm{w}$ siebie, co może być bardzo przydatne w przyszłości, kiedy to po zakończeniu edukacji będą starali się odnaleźć w dorosłym życiu. Doświadczenia zebrane podczas takich wyjazdów na pewno będą procentowały podczas poszukiwań pracy, zawarte wówczas znajomości mogą sprzyczynić się do tego, że rozpoczną swoją karierę poza granicami Polski, a kontakt z obcym językiem pozwoli im na jego efektywniejszą naukę.

\section{BIBLIOGRAFIA}

Kaczmarczyk P., Okólski M., Migracje specjalistów wysokiej klasy w kontekście cztonkostwa Polski w Unii Europejskiej, UKIiE, Warszawa 2005.

Kawczyńska-Butrym Z., Migracje. Wybrane zagadnienia, Lublin 2009.

Kisiel A., Postawy migracyjne studentów. Studium na przyktadzie Rybnika, [w:] Spoteczności lokalne: postawy migracyjne mtodych Polaków, red. A. Śliz, Wydawnictwo Uniwersytetu Opolskiego, Opole 2008. 
Kubiak H., Slany K., Migracje, [hasło w:] Encyklopedia socjologii, red. Z. Bokszański, Oficyna Naukowa, Warszawa 2002.

Kubiak L., Spoteczno-ekonomiczne skutki migracji Polaków po akcesji Polski do Unii Europejskiej, Prace Naukowe nr 1(54),Wydawnictwo Wyższej Szkoły Ekonomicznej ALMAMER, Warszawa 2009.

Mamzer H., Tożsamość w podróży. Wielokulturowość a ksztattowanie tożsamości jednostki, Wydawnictwo Naukowe Uniwersytetu Adama Mickiewicza, Poznań 2003.

Romaniuk N., Dialektyka wyzwań i zagrożeń bezpieczeństwa: aspekt migracyjny, [w:] Migracja - wartość dodana, red. K. Markowski, Wydawnictwo Katolickiego Uniwersytetu Lubelskiego, Lublin 2008.

Slany K., Między przymusem a wyborem: kontynentalne i zamorskie emigracje z krajów Europy Środkowo-Wschodniej, Wydawnictwo Uniwersytetu Jagiellońskiego, Kraków 1995.

Śliz A., Od podboju do dialogu kultur. Polskie migracje w kontekście procesu globalizacji. Zamiast wprowadzenia, [w:] Spoteczności lokalne: postawy migracyjne mtodych Polakórw, red. A. Sliz, Wydawnictwo Uniwersytetu Opolskiego, Opole 2008.

Wierzbicki A., Spoteczne aspekty migracji w kontekście integracji z Uniq Europejska, [w:] Swobodny przeptyw pracowników w kontekście wejścia Polski do Unii Europejskiej, UKIE, Warszawa 2001.

„Biuletyn migracyjny”, Ośrodek Badań nad Migracjami Uniwersytetu Warszawskiego, nr 2/sierpień 2005, Warszawa 2005.

\section{EXPERIENCES OF INTERNATIONAL LABOUR EMIGRATION AS EXEMPLIFIED BY THE STUDENTS OF WROC ŁAW UNIVERSITY OF ECONOMICS} SUMMARY

The article briefly presents the phenomenon of migration and classifies it according to certain criteria. Moreover, in his work the author has used some of the results of research carried out among students of Wroclaw University of Economics. Data obtained from the survey made it possible to determine the size of the existing international labour migration of students, its direction, and the motives of this type of emigration. The article discusses the financial issues associated with this travelling and tries to determine other benefits of these journeys. 